\title{
Phylogenetic patterns in the tribe Acacieae (Caesalpinioideae: Fabaceae) based on $r b c L$, matK, trnL-F and ITS sequence data
}

\author{
Aramide Dolapo Igbari* and Oluwatoyin Temitayo Ogundipe \\ Molecular Systematics Laboratory, Department of Botany, University of Lagos, Akoka, Yaba, Lagos, Nigeria
}

Received 13th December 2018 / Accepted 22nd April 2019

\begin{abstract}
The tribe Acacieae is one of the three tribes of the distinct mimosoid clade nested within the re-circumscribed sub-family Caesalpinioideae. Many uncertainties exist with the taxonomic status of tribe Acacieae in relation to tribe Ingeae and genus Acacia. To unravel the phylogenetic patterns within Acacieae, nine members of the tribe were phylogenetically analysed employing both parsimony and Bayesian methods. Six data matrices (ITS, $r b c L$, matK, $t r n L-F, r b c L+m a t K+t r n L-F$ and ITS $+r b c L+m a t K+t r n L-F$ ) representing 46 sequences, and 2 outgroup taxa were used for the analysis. Our results are in support to some previous studies on the phylogeny of the Acacieae. It supports the polyphyly of tribe Acacieae. The monophyly of Vachellia, Senegalia and Faidherbia taxa were strongly supported at $>70 \%$ bootstrap support values and $>0.90$ bayesian inference. An unresolved basal paraphyletic clade of Acacia auriculiformis with the outgroup taxa was shown in all the datasets, at mostly low support values. Faidherbia albida was nested within the Senegalia grade while $A$. auriculiformis (Acacia s.s.) was the closest taxon to the outgroup taxa. A key finding of this study is the polyphyly of Albizia and its close association with $A$. auriculiformis.
\end{abstract}

Keywords: African Acacias, molecular phylogeny, Ingeae, cp DNA, nr DNA

\section{INTRODUCTION}

The tribe Acacieae is one of the three tribes of the distinct mimosoid clade (Mimosoideae) nested within the re-circumscribed sub-family Caesalpinioideae (LPWG 2017). Tribe Acacieae was formally grouped with many genera that are today classified in tribe Ingeae Benth (Bentham 1842). Initially, Bentham (1875) restricted the genus Acacia Mill. to the Acacieae as the only member of the tribe. Today, tribe Acacieae is now regarded to comprise just two genera, the very large cosmopolitan genus Acacia s.l. and the monotypic genus Faidherbia A. Chev. (Chappill and Maslin 1995; Miller and Bayer 2000; Miller et al., 2003; Murphy et al., 2010). However, many uncertainties still exist, not only with the status of tribe Acacieae, especially in relation to tribe Ingeae and to a lesser extent tribe Mimoseae, but also with the definition, classification, and phylogeny of genus Acacia (Luckow et al., 2000; Maslin et al., 2003; Miller et al., 2003; Murphy et al., 2010). More recently, Miller and Seigler (2012) noted that the tribal relationships within the mimosoid clade are now in disarray, and new phylogenetic data is imperative for establishing an acceptable tribal and generic system of classification of the Mimosoideae.

Members of tribe Acacieae are generally trees or shrubs, they are distinguished by an indefinite number of stamens (more than 10) that are usually free or united only at the base and valvate calyx (Elias, 1981; Vassal, 1981). Individual flowers are arranged in inflorescences that may be either globular heads or cylindrical spikes. However, these features are not only unique to the tribe. In

*Author for correspondence: Aramide Dolapo Igbari, Molecular Systematics Laboratory, Department of Botany, University of Lagos, Akoka, Yaba, Lagos, Nigeria. Email - dlparamide2012@gmail.com 
fact, no single morphological character distinguishes Acacieae from other tribes in subfamily Mimosoideae, and this has called into question the monophyly of Acacieae and the other tribes in the Mimosoideae (Chappill and Maslin, 1995). The main character that distinguishes the Acacieae from the Ingeae, are free filaments of the stamens while the Ingeae have united filaments. However, this is not entirely maintained in all taxa, some Acacia species have filaments shortly united at the base (Vassal, 1981; Miller et al., 2003; Murphy et al., 2010). Additionally, numerous stamens and eight polyads per anther are other characters also shared between the two tribes (Chappill and Maslin, 1995). The close relationship of the Ingeae and Acacieae has already been observed (Guinet, 1981; Vassal, 1981) and the conflicting character states have made classification that is solely based on morphological characters difficult.

Furthermore, the relationship of the Faidherbia genus with Acacia is controversial. The genus has shortly united stamens and pollens similar to some taxa of the Ingeae but was placed in the Acacieae (Guinet, 1981). Hence, ensuing some ongoing debate as to whether Faidherbia is better placed in the tribe Ingeae or Acacieae (Elias, 1981; Guinet, 1990; Lewis and Rico-Arce, 2005). The non-monophyly of Acacieae and Ingeae are particularly problematic, with the recognition of monophyletic taxa requiring the generic revision of Acacia s.l. (Miller et al., 2003b). This has contributed to a highly controversial debate about the application of the name Acacia (Pedley, 1986; Maslin et al., 2003a; b; Luckow et al., 2005b).

Albeit, because the tribe Acacieae constitute a large and morphologically heterogenous group, an infrageneric classification based on phylogenetic relationships has become imperative and cardinal for other studies such as: host-parasite coevolution (Crespi et al., 2004; McLeish et al., 2007); plant physiology (Pohlman et al., 2005; Warwick and Thukten, 2006); atmospheric nitrogen fixation in relation to rhizobial interactions (Brockwell et al., 2005); and insects' radiations associated with Acacia (Austin et al., 2004) amongst others.

Therefore, the objective of this study is to elucidate on the phylogenetic relationship of the tribe Acacieae in order to test the monophyly of the tribe and establish relationships between its two genera in relation to tribe Ingeae. Similarly, the former, broadly circumscribed genus Acacia Mill. is polyphyletic and has been segregated into five genera, Acacia s.s., Acaciella Britton \& Rose, Mariosousa Seigler \& Ebinger, Senegalia Raf. and Vachellia Wight \& Arn (Maslin, 2015). This study also tests the monophyly of the two groups of Acacia s.l. (Senegalia and Vachiellia) that abound in Africa employing molecular systematic techniques and data from three chloroplast regions ( $r b c L$, $m a t K, \operatorname{trn} L-F)$ and the nuclear ITS region.

\section{MATERIALS AND METHODS}

Plant material. Thirty-two samples of Acacia species representing six species were randomly collected from the arid and semi-arid region of Nigeria while sequences of two other species $(A$. karroo \& $A$. tortilis) were downloaded from GenBank. Two outgroup species Albiziia lebbeck and Albizzia zygia were included. These outgroup taxa were selected based on results of previous studies, which indicate members of the Ingeae as sister to Acacia (Brown et al., 2008). Collected samples were identified and authenticated at the University of Lagos Herbarium (LUH). The voucher number, GenBank and other information about samples are given in Appendix 1.

DNA extraction and amplification. Total genomic DNA was isolated from approximately $0.0300 \mathrm{~g}$ of silica-gel dried and $0.0180 \mathrm{~g}$ of herbarium plant material following a modified $2 \mathrm{X}$ CTAB protocol of Doyle and Doyle (1987). Herbarium samples were precipitated for one week while silica dried for $1 \mathrm{hr}$. Extracted DNA was stored at $-20^{\circ} \mathrm{C}$ prior subsequent use. Polymerase chain reaction (PCR) was performed in $50 \mu \mathrm{l}$ reaction mixtures containing $25 \mu \mathrm{l}$ biomix, $1 \mu \mathrm{l} \mathrm{BSA}, 2 \mu \mathrm{l}$ DMSO, $1.75 \mu \mathrm{l}$ of $10 \mu \mathrm{M}$ of each primer, $17.5 \mu \mathrm{l}$ of Millipore $\mathrm{H}_{2} \mathrm{O}$ and $1 \mu \mathrm{l}$ of 30 $50 \mathrm{ng}$ template DNA. The Kim matK primers were used to amplify matK region while primers according to Sun et al. (1994), Olmstead et al. (1992) and Taberlet et al. (1991) were used for ITS, $r b c L$ and $t r n L-F$ regions respectively. PCR profiles run for each region are given on Table 1. Amplifications were run on a Veriti ${ }^{\circledR} 96$ well 
thermal cycler. Each PCR product was run on 1\% agarose gel stained in ethidium bromide and successful amplified products were sent to Source Bioscience (UK) for bidirectional sequencing using the same primer used in PCR.

Phylogenetic analysis. Chromatographic traces and contiguous alignments were edited using Sequencher 3.0 (Gene Codes Corporation, Ann Arbor, Michigan). Any uncertain base positions, generally located close to the priming sites, and regions of uncertain alignment were excluded from the phylogenetic analysis. Sequences were aligned and edited in Bioedit (Hall, 1999). Informative insertion/deletion events (indels) were identified and coded as binary characters, and gaps were treated as missing data. All four regions were analyzed separately, a combined data matrix of three chloroplast regions and the combined data matrix of the four regions were also analysed. Less than $1 \%$ of the data were scored as missing.

Parsimony analyses were performed on the aligned sequences using heuristic search in PAUP 4b10 (Swofford 2002) with nucleotide substitutions equally weighted and unordered. Heuristic search was used with tree-bisectionand-reconnection and random sequence addition. Bootstrap analysis was also performed to test the robustness of each clade with random addition of sequences 1000 replicates. A Bayesian analysis (Ronquist et al., 2011) was carried out by first determining the optimal substitution model using MrModeltest v2.3 (Nylander, 2004) and the Akaike information criterion. The general reversible model with a gamma shape $(\mathrm{GTR}+\mathrm{G})$ was selected for the trnL-F region; HasegawaKishono-Yano with a proportion of invariable sites $(\mathrm{HKY}+\mathrm{I})$ for matK; Hasegawa-KishonoYano with a gamma shape and a proportion of invariable sites $(\mathrm{HKY}+\mathrm{I}+\mathrm{G})$ for $r b c \mathrm{~L}$ region whereas Hasegawa-Kishono-Yano with a gamma shape $(\mathrm{HKY}+\mathrm{G})$ was specified for the nuclear ITS region. Four discrete states were used for the gamma substitution. The data were therefore partitioned into two for the Bayesian analysis and the correct substitution model as specified by MrModeltest was specified for each partition. The partitions were unlinked so that each parameter could be specified separately. Analysis was run for 30,000,000 generations with sampling every 30,000 generations. Metropolis coupling with four chains, one cold and three heated were used with the two independent runs running simultaneously. The runs, however stopped (split standard deviation set at 0.01) after 7705000 generations and 7705 sampled trees in each run. Approximately $24.7 \%(7,410,000)$ trees were used as burnin in summarizing the parameters and tree. The robustness of each clade was ascertained based on the posterior probability as an inference on the validity of the tree.

Table 1. Amplification profiles.

\begin{tabular}{ccccccc}
\hline Region & $\begin{array}{c}\text { Initial denaturing } \\
\text { Temp./time }\end{array}$ & $\begin{array}{c}\text { Denaturation } \\
\text { Temp./time }\end{array}$ & $\begin{array}{c}\text { Annealing } \\
\text { Temp./time }\end{array}$ & $\begin{array}{c}\text { Extension } \\
\text { Temp./time }\end{array}$ & $\begin{array}{c}\text { Final extension } \\
\text { Temp./time }\end{array}$ & $\begin{array}{c}\text { No. of } \\
\text { cycles }\end{array}$ \\
\hline ITS & $97^{\circ} \mathrm{C} / 2: 00$ & $97^{\circ} \mathrm{C} / 1: 00$ & $55^{\circ} \mathrm{C} / 0: 45$ & $72^{\circ} \mathrm{C} / 0: 45$ & $72^{\circ} \mathrm{C} / 7: 00$ & 30 \\
matK & $94^{\circ} \mathrm{C} / 5: 00$ & $94^{\circ} \mathrm{C} / 0: 40$ & $48^{\circ} \mathrm{C} / 0: 40$ & $72^{\circ} \mathrm{C} / 0: 40$ & $72^{\circ} \mathrm{C} / 7: 00$ & 30 \\
rbcL & $96^{\circ} \mathrm{C} / 0: 50$ & $96^{\circ} \mathrm{C} / 0: 50$ & $53^{\circ} \mathrm{C} / 0: 50$ & $72^{\circ} \mathrm{C} / 2: 00$ & $72^{\circ} \mathrm{C} / 7: 00$ & 30 \\
trnL-F & $94^{\circ} \mathrm{C} / 2: 00$ & $94^{\circ} \mathrm{C} / 1: 00$ & $55^{\circ} \mathrm{C} / 1: 00$ & $72^{\circ} \mathrm{C} / 2: 00$ & $72^{\circ} \mathrm{C} / 10: 00$ & 30 \\
\hline
\end{tabular}

\section{RESULTS}

In this present study, eight Acacia s.l. and two outgroup (Albizia) species were examined for phylogenetic patterns employing 3 chloroplast regions and the nuclear ITS region. A total of 29 taxa were successfully sequenced for mat $K$ and trnL-F regions, 26 taxa for $r b c L$ region while 23 taxa for the nuclear ITS region. Results of parsimony analysis and tree description for each examined gene region is summarized on Table 2. The strict consensus tree of all combined chloroplast region (Figure 1) revealed an unresolved basal clade of $A$. auriculiformis with outgroup taxa but at high support value of $99 \%$. It also depicted a closer relationship of Faidherbia albida with the outgroup taxa, the monophyly of Senegalia and Vachellia was also observed. The topology of all the combined data (Figure 2) is 
congruent with the combined chloroplast regions. An unresolved basal entity and close relationship of $A$. auriculiformis and $F$. albida with the outgroup species is revealed. The strict consensus tree of ITS region Figure 3 revealed the base of the tree is well resolved with a paraphyletic F. albida and distinct clades of Senegalia and Vachellia species. There are good bootstrap support values of $>70 \%$ for each monophyletic group. The strict consensus matK gene tree (Appendix 2a) revealed an unresolved paraphyletic clade of outgroup taxa and $A$. auriculiformis at a low support value of 51.7\%. Vachellia, Senegalia and Faidherbia taxa exhibited a monophyletic relationship at high bootstrap value. However, some low support values were recorded. $r b c L$ strict consensus gene tree (Appendix 2b, Supplementary Data) revealed an unresolved paraphyletic base at low support value of $35.11 \%, A$. auriculiformis was clustered with the outgroup taxa whereas Vachellia, Faidherbia and Senegalia taxa were monophyletic. Relationships were mostly depicted at low support values. The last chloroplast trnL-F strict consensus gene tree depicted an unresolved basal clade (Appendix 2c,). Other Acacieae species, Senegalia, Vachellia and Faidherbia are monophyletic whereas $A$. auriculiformis was clustered with the outgroup taxa at low support value of $30.13 \%$.
Robustness of most clades were at high bootstrap support values of $>70 \%$.

Bayesian analysis showed a higher resolution of species cluster at distinct node with a quite high posterior probability. A similar topology was observed with the parsimony results. Although the trees from the Bayesian analysis are somewhat similar in topology from the parsimony analysis. Bayesian phylogram of the combined chloroplast and all combined dataset (Figures 4 and 5) established a closer association of $A$. auriculiformis with the outgroup taxa at 0.6 BI and likewise a close relationship of $F$. albida. ITS gene tree Bayesian analysis (Figure 6) revealed a well resolved basal taxa and a close relationship of $F$. albida with the outgroup taxa. matK gene tree (Appendix 2d) revealed a monophyletic Senegalia and Vachellia at high bayesian inference of 1.00. However, an unresolved basal entity was observed. Bayesian phylogram of $r b c L$ region (Appendix 2e) showed an unresolved basal relationship of $A$. auriculiformis and the outgroup taxa at 0.92 BI. However, members of the Vachellia taxa were closer to the outgroup taxa than F. albida. trnL-F bayesian phylogram (Appendix 2f) also revealed an unresolved basal entity at $0.50 \mathrm{BI}$, and a close relationship of $F$. albida with the outgroup clade.

Table 2. Parsimony profiles and tree description.

\begin{tabular}{|c|c|c|c|c|c|c|c|c|c|}
\hline $\begin{array}{l}\text { Gene } \\
\text { region }\end{array}$ & $\begin{array}{c}\text { Total } \\
\text { number of } \\
\text { characters }\end{array}$ & $\begin{array}{l}\text { Constant } \\
\text { characters }\end{array}$ & $\begin{array}{l}\text { Variable } \\
\text { characters }\end{array}$ & $\begin{array}{l}\text { Parsimony } \\
\text { informative } \\
\text { characters }\end{array}$ & $\begin{array}{c}\text { Tree } \\
\text { length }\end{array}$ & $\begin{array}{l}\text { Restriction } \\
\text { index } \\
(\mathrm{RI})\end{array}$ & $\begin{array}{l}\text { Homoplasy } \\
\text { index } \\
\text { (HI) }\end{array}$ & $\begin{array}{l}\text { Consistency } \\
\text { index } \\
\text { (CI) }\end{array}$ & $\begin{array}{c}\text { Rescaled } \\
\text { consistency } \\
\text { index } \\
(\mathrm{RC}) \\
\end{array}$ \\
\hline ITS & 783 & 486 & 59 & 238 & 531 & 0.9301 & 0.2147 & 0.7304 & 0.7304 \\
\hline matK & 935 & 877 & 20 & 38 & 62 & 0.9895 & 0.0323 & 0.9677 & 0.9576 \\
\hline$r b c L$ & 1331 & 1249 & 33 & 49 & 107 & 0.9298 & 0.1963 & 0.8037 & 0.7473 \\
\hline trnL-F & 1168 & 1049 & 41 & 81 & 147 & 0.9571 & 0.1429 & 0.8571 & 0.8204 \\
\hline $\begin{array}{c}\text { mat } K+r b c L+ \\
\text { trnL-F }\end{array}$ & 3434 & 3172 & 94 & 168 & 340 & 0.9306 & 0.2776 & 0.7224 & 0.7445 \\
\hline $\begin{array}{l}\text { ITS }+ \text { matK+ } \\
r b c L+t r n L-F\end{array}$ & 1427 & 3658 & 153 & 406 & 871 & 0.9303 & 0.2090 & 0.7910 & 0.7359 \\
\hline
\end{tabular}




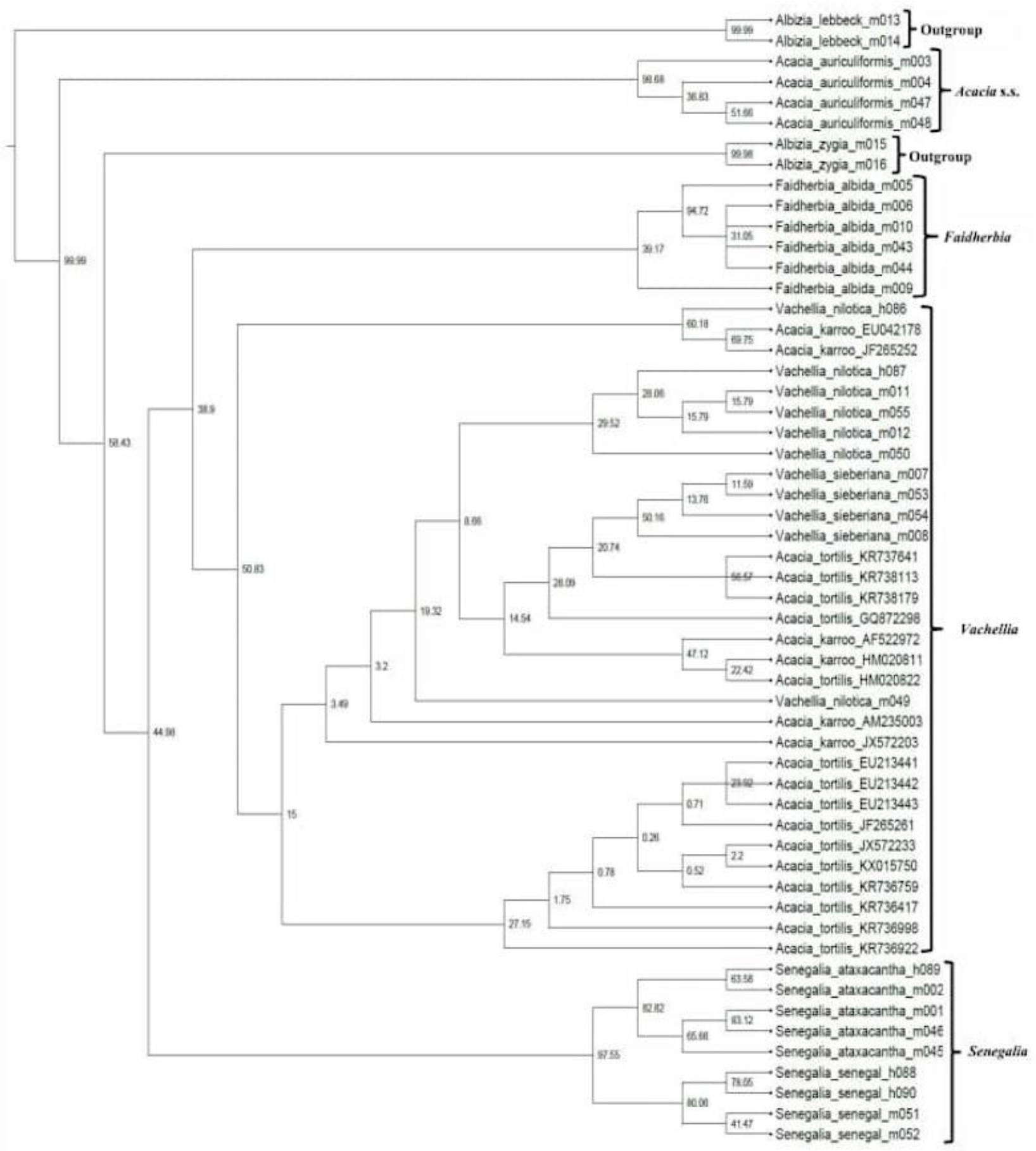

Figure 1. Maximum parsimony phylogram of the original tree $(m a t K+r b c L+t r n L-F)$; numbers at node indicates bootstrap support values. 


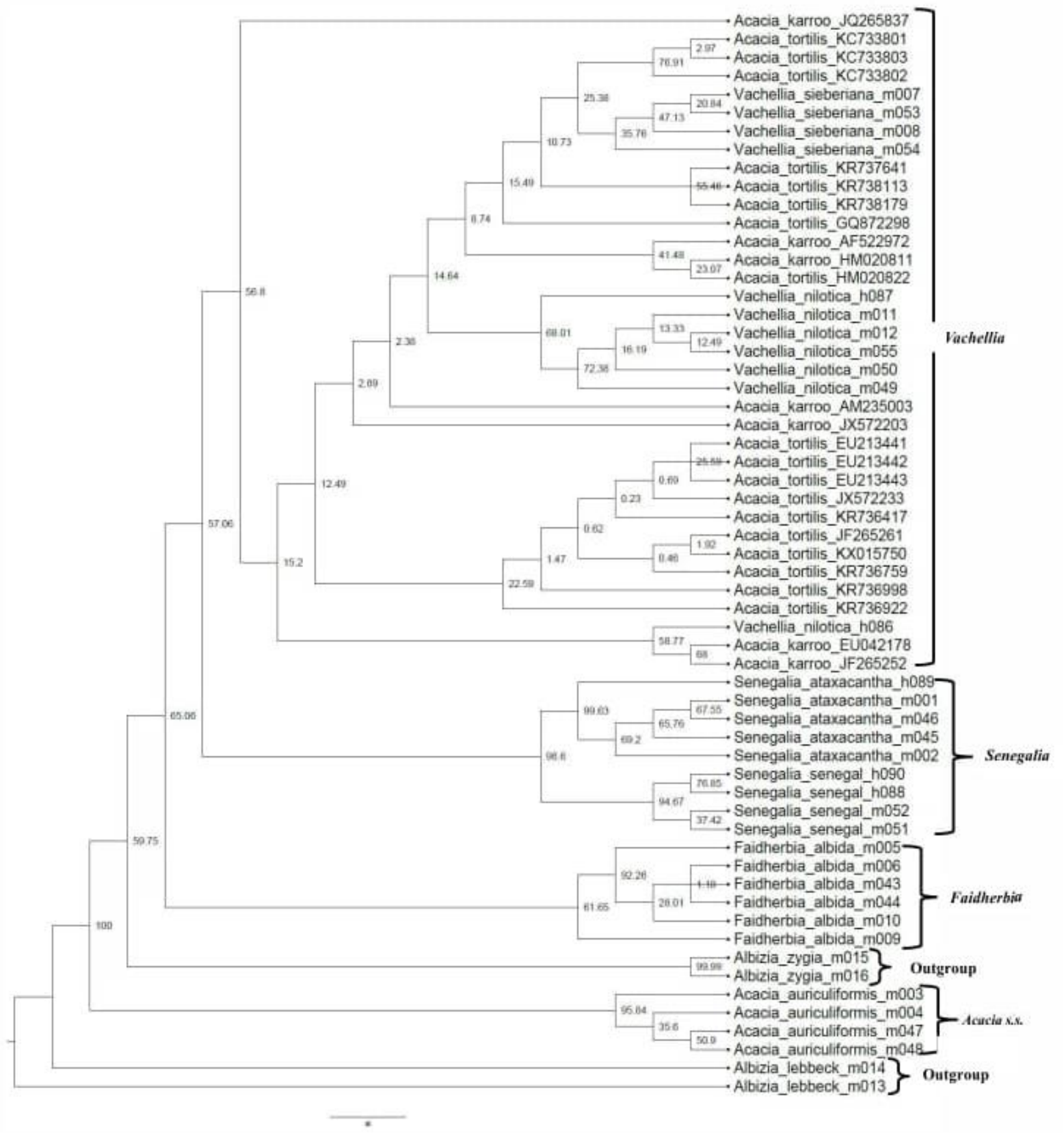

Figure 2. Maximum parsimony phylogram of the original tree (ITS + mat $K+r b c L+\operatorname{trn} L-F)$; numbers at node indicates bootstrap support values. 


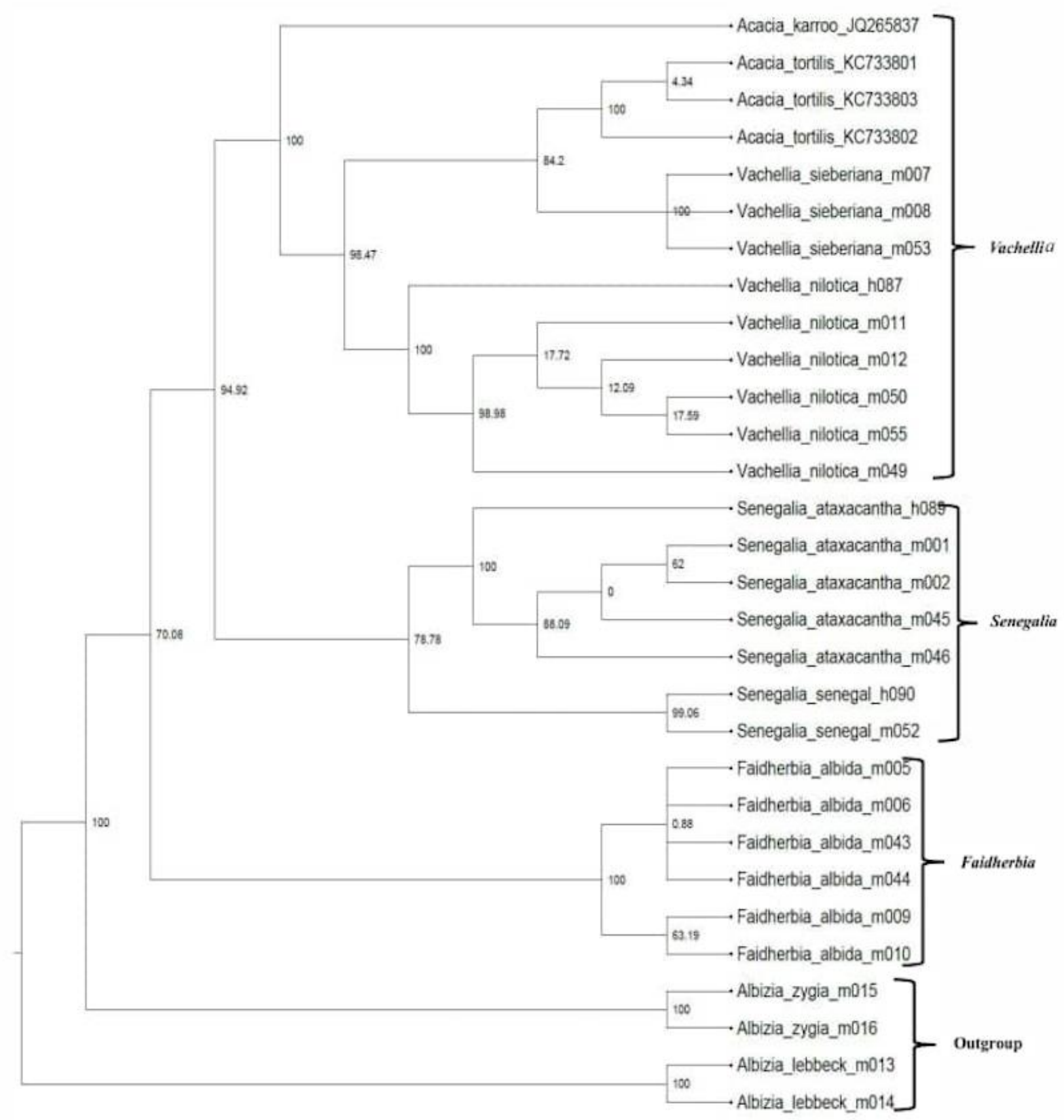

Figure 3. Maximum parsimony phylogram of the original tree (ITS); numbers at node indicates bootstrap support values. 


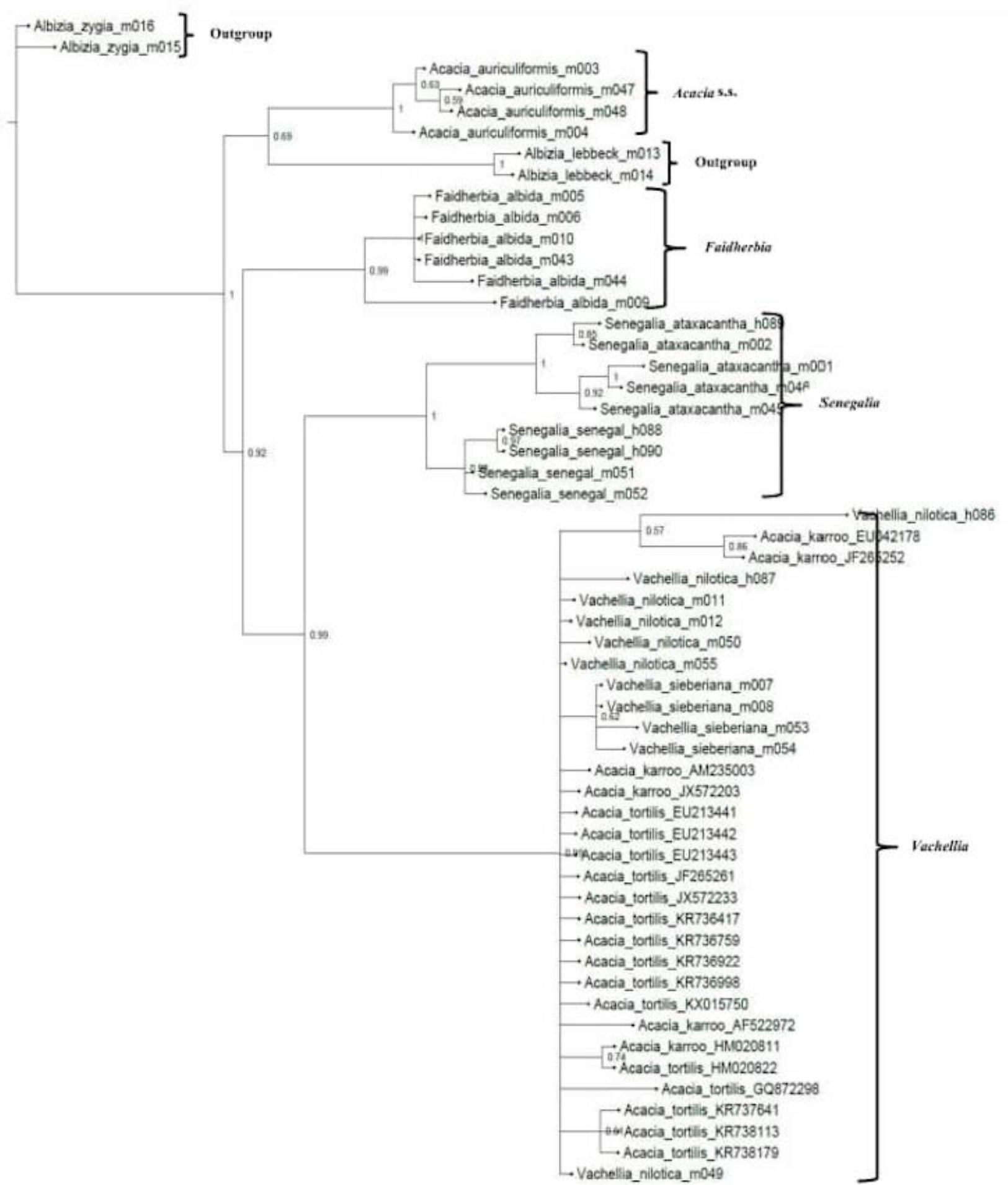

Figure 4. Phylogram inferred by Bayesian analysis $(m a t K+r b c L+t r n L-F)$; numbers at node indicates posterior probability values. 


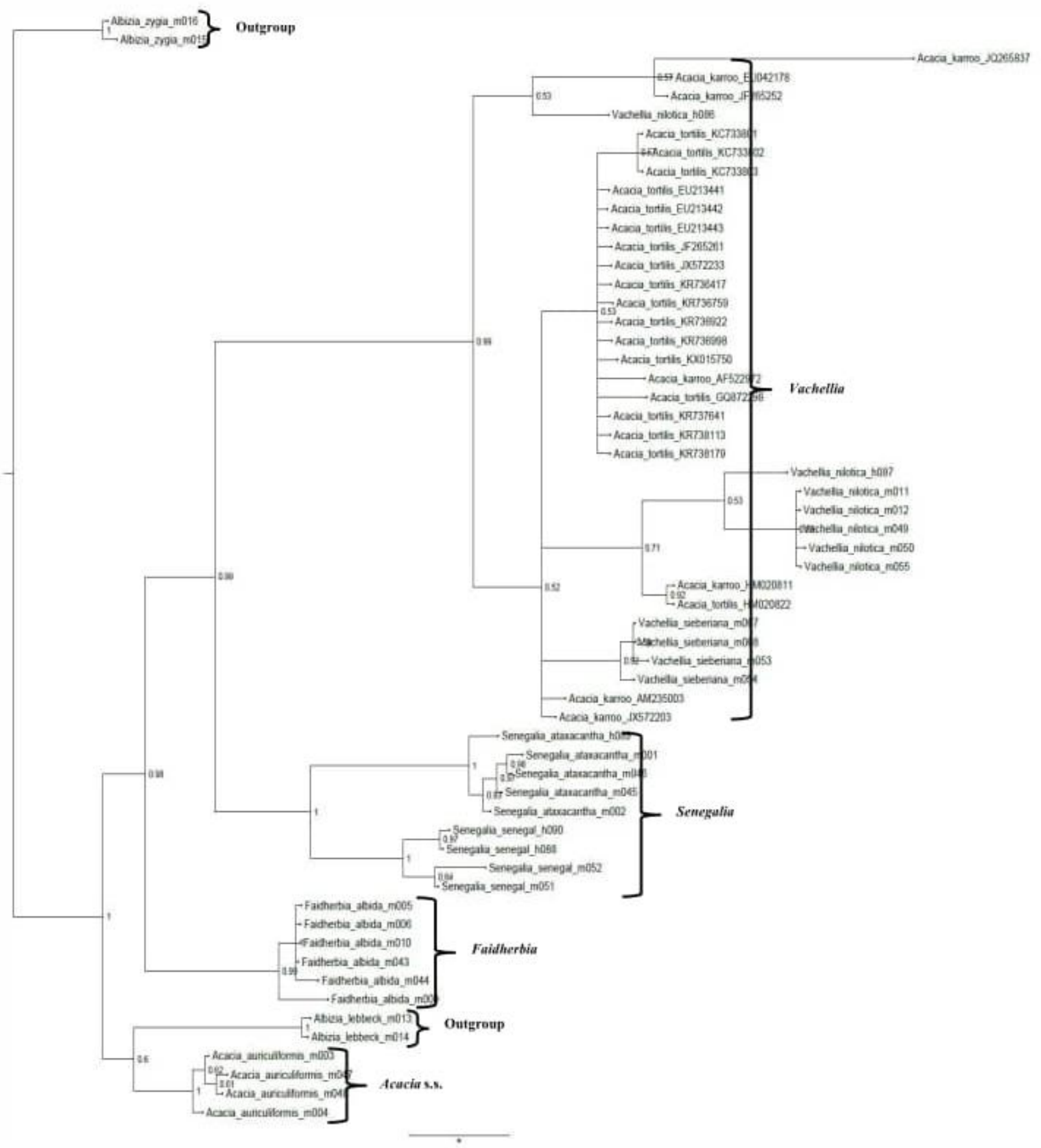

Figure 5. Phylogram inferred by Bayesian analysis (ITS + mat $K+r b c L+\operatorname{trn} L-F)$; numbers at node indicates posterior probability values. 


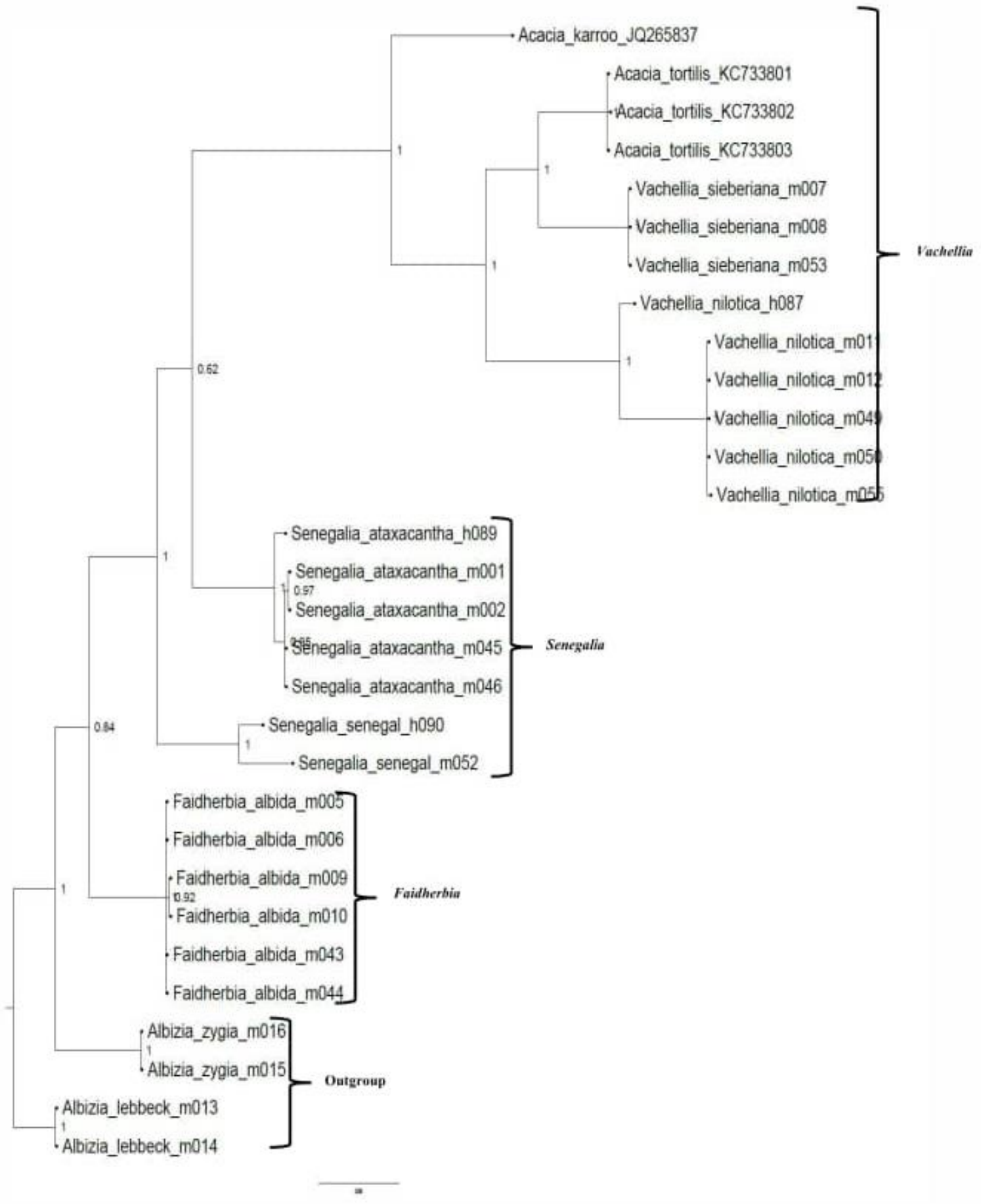

Figure 6. Phylogram inferred by Bayesian analysis (ITS); numbers at node indicates posterior probability values.

\section{DISCUSSION}

The phylogenetic pattern of the tribe Acacieae based on three chloroplasts (matK, rbcL, trnL-F) region and the nuclear ITS region was elucidated in order to test the monophyly of the tribe and establish relationships between its two genera in relation to tribe Ingeae. Combined data matrix of the three chloroplast regions and a combined data matrix of the four regions were also analyzed. Based on both parsimony and bayesian methods, results revealed the polyphyly of tribe Acacieae. An unresolved basal paraphyletic clade of $A$. auriculiformis with the outgroup taxa was shown in 
all the datasets, at mostly low support values. Results support the monophyly of Vachellia, Senegalia and Faidherbia taxa.

Our results are in support to some previous studies on the phylogeny of the Acacieae. The polyphyly of the tribe Acacieae were equally found in some previous studies: Luckow et al. $(2000,2003)$ based on plastid trnL, trnK intron and matK gene sequences; Miller et al. (2003) based on trnK, matK, $p s b A-t r n H$, and $t r n L-F$ sequence data. Considerable attention has also been devoted in recent phylogenetic studies to unravel the nonmonophyly of Acacia s.l. Numerous analyses have established clear support for at least five independent lineages scattered widely across the mimosoid clade: Vachellia, Acacia s.str., Acaciella, Senegalia and Mariosousa (Miller and Bayer, 2001, 2003; Luckow et al., 2003; Maslin et al., 2003; Seigler et al., 2006b; Bouchenak-Khelladi et al., 2010; Miller and Seigler, 2012). These studies suggest a non-monophyletic Senegalia. However, based on our dataset, Senegalia is monophyletic. It exhibited a close association with Faidherbia albida.

The affinities of the monotypic genus Faidherbia has been controversial. Grimes (1999) found Faidherbia as sister to the Acacia subg. Acacia whereas, Maslin (1995), presented two conflicting relationships of Faidherbia nested within either the Ingeae or Acacia subg Aculeiferum grade. Polhill (1994), Maslin and Stirton (1997), Robinson and Harris (2000), and Maslin et al. (2003) classified F. albida to be closer to the Ingeae. However, in our analysis F. albida is nested within the Senegalia grade while $A$. auriculiformis (Acacia s.s) was the closest taxon to the outgroup taxa. Results from these analyses support the current classification of F. albida within the tribe Acacieae.

In our study, the polyphyly of Albizia was observed. This support some previous studies of Grimes (1999), Polhill (1994), Luckow et al. (2000, 2003), Sulaiman et al. (2003), Lewis et al. (2005), and Shinwari et al. (2014), which found a lack of resolution and support in the Acacia sstr and Albiria. Although the genus Albiria was selected as the outgroup taxa, the unresolved cluster of the basal outgroup taxa with Acacia sstr ( $A$. auriculiformis) could likely be attributed to the polyphyly of the Albizia (Luckow, 2003). This could probably be as a result of our limited taxon sampling of Acacia s.s. A powerful solution will likely be found in a denser species sampling and highly variable character selection (Doyle et al., 1997; Wojciechowski et al., 2004; Lavin et al., 2005). A key finding of this study is the polyphyly of Albizia and its close association with Acacia s.s. Acacia.

In summary, the phylogeny based on both chloroplast and nuclear DNA confirms the polyphyly of Acacieae and paraphyly of tribe Ingeae. Our results show that Ingeae and Acacia s.s. together form an unresolved basal entity. Furthermore, the monophyly of Vachellia and Senegalia taxa at high support values were also indicated. However, the relationship between the Ingeae and Acacia s.s still remain unresolved. This study is a maiden attempt to resolve the intergeneric relationships of tribe Ingeae and Acacia s.s. however, based on traditional generic concepts and recent molecular phylogenetic findings, some large genera e.g. Albizia are potentially polyphyletic. Phylogenetic patterns of additional gene regions should be explored as well as a more detailed taxon sampling of morphologically variable genera.

\section{ACKNOWLEDGEMENTS}

The authors would like to thank Alastair Culham for providing laboratory space and his insightful perspectives and helpful suggestions during the laboratory work. We are grateful to the Stellenbosch University summer school course on scientific writing for novices in Life Science for helpful suggestions to improve the manuscript. Funding: This work was supported by the UNESCO-L'Oréal for Women in Science International fellowship for bench work and other logistics (REF: SC/PCB/SPR/CDC/14.14 \& 15.32: Molecular Characterization, DNA Barcoding and Conservation of Arid Fabaceae in Nigeria). We also acknowledge the help of the Competitive Agricultural Research Grant Scheme (CARGS) project for sponsoring the field work and sampling.

\section{REFERENCES}

Austin, A. D., Yeates, D. K., Cassis, G., Fletcher, M. J., La Salle, J., Lawrence, J. F., McQuillan, P. B., Mound, L. A., Bickel, D. 
J., Gullan, P. J., Hales, D. F., \& Taylor, G. S. 2004. Insects Down Under diversity, endemism and evolution of the Australian in sect fauna: Examples from select orders. Australian Journal of Entomology 43: 216-234.

Bentham, G. 1842. Notes on Mimosoideae, with a synopsis of species. London Journal Botany 1: 494-528.

Bentham, G. 1875. Revision of the suborder Mimoseae. Transactions of the Linnaean Society London, 30: 335-664.

Bouchenak-Khelladi, Y., Maurin, O., Hurter, J., \& Van der Bank, M. 2010. The evolutionary history and biogeography of Mimosoideae (Leguminosae): an emphasis on African acacias. Molecular Phylogenetics and Evolution 57: 495- 508.

Brockwell, J., Searle, S. D., Jeavons, A. C., \& Waayers, M. 2005. Nitrogen fixation in Acacias: an untapped resource for sustainable plantations, farm forestry and land reclamation. ACIAR Monograph No. 115. Australian Centre for International Agricultural Research: Canberra.

Brown, G. K., Murphy, D. J., Miller, J. T., \& Ladiges, P. Y. 2008. Acacia s.s. and its relationship among tropical legumes, tribe Ingeae (Leguminosae: Mimosoideae). Systematic Botany 33: 739-751.

Byrne, M., Tischler, G., Macdonald, B., Coates, D. J., \& McComb, J. 2001. Phylogenetic relationships between two rare acacias and their common, widespread relatives in south-western Australia. Conservation Genetics 2: 157-166.

Chappill, J. A. \& Maslin, B. R. 1995. A phylogenetic assessment of Tribe Acacieae. In: Advances in Legume Systematics. Part 7, pp. 77-99. Royal Botanic Gardens, Kew.

Crespi, B. J., Morris, D. C., \& Mound, L. A. 2004. Evolution of ecological and behavioural diversity: Australian Acacia thrips as model organisms. Australian Biological Resources Study \& Australian National Insect Collection, CSIRO, Canberra, Australia.

Doyle, J. J. \& Doyle, J. L. 1987. A rapid DNA isolation procedure for small quantities of fresh leaf tissue. Phytochemical Bulletin 19: 11-15.

Doyle, J. J., Doyle, J. L., Ballenger, J. A., Dickson, E. E., Kajita, T., \& Ohashi, H. 1997. A phylogeny of the chloroplast gene rbcL in the Leguminosae: taxonomic correlations and insights into the evolution of nodulation. American Journal of Botany 84: 541-554.

Elias, T. 1981. Mimosoideae. In: Advances in Legumes Systematics. Part 1, pp. 143-151. Royal Botanic Gardens, Kew.

Fay, M. F., Swensen, S. M., \& Chase, M. W. 1997. Taxonomic affinities of Medusagyne oppositifolia (Medusagynaceae). Kem Bulletin 52: 111-120.

Grimes, J. 1999. Inflorescence morphology, heterochrony, and phylogeny in the mimosoid tribes Ingeae and Acacieae (Leguminosae: Mimosoideae). Botanical Review 65: 317-347.

Guinet, P. 1981. 'Mimosoideae: the characters of their pollen grains'. In: Advances in Legume Systematics. Part 2, pp. 835-855. Royal Botanic Gardens, Kew.

Guinet, P. 1990. The genus Acacia (Leguminosae, Mimosoideae): its affinities as borne out by its pollen characters. Plant Systematics and Evolution (supplement) 5: 81-90.

Hall, T. A. 1999. BioEdit: a user-friendly biological sequence alignment editor and analysis program for Windows 95/98/NT. Nucleic Acids Symposium Series 41:95-98.

Lavin, M., Herendeen, P. S., \& Wojciechowski, M. F. 2005. Evolutionary rates analysis of Leguminosae implicates a rapid diversification of lineages during the tertiary. Systematic Biology 54: 575-594.

Lewis, G. P. \& Rico-Arce, M. L. 2005. Tribe Ingeae. In: Legumes of the World. pp. 193-213. Royal botanic Gardens, Kew, Richmond, Surrey UK.

Lewis, G., Schrire, B., MacKinder, B., \& Lock, M. 2005. Legumes of the world. Royal Botanical Gardens, Kew, UK.
Legume Phylogeny Working Group (LPWG). 2017. A new subfamily classification of the Leguminosae based on a taxonomically comprehensive phylogeny. Taxon 66(1): 44 77.

Luckow, M., Miller, J. T., Murphy, D. J., \& Livshultz, T. 2003. A phylogenetic analysis of the Mimosoideae (Leguminosae) based on chloroplast DNA sequence data. In: Advances in Legume Systematics. Part 10, pp. 197-220. Royal Botanic Gardens, Kew.

Luckow, M., White, P. J., \& Bruneau, A. 2000. Relationships among the basal genera of mimosoid legumes. In: Advances in Legume Systematics. Part 9, pp. 165-180. Royal Botanic Gardens, Kew.

Luckow, M., Hughes, C. E., Schrire, B., Winter, P., Fagg, C., Fortunato, R., Hurter, J., Rico, L., Breteler, F. J., Bruneau, A., Caccavari, M., Craven, L., Crisp, M., Delgado, A., Demissew, S., Doyle, J. J., Grether, R., Harris, S., Herendeen, P. S., Hernández, H. M., Hirsch, A. M., Jobson, R., Klitgaard, B. B., Labat, J. N., Lock, M., MacKinder, B., Pfeil, B., Simpson, B. B., Smith, G. F., Sousa, M., Timberlake, J., van der Maesen, J. G., Van Wyk, A. E., Vorster, P., Willis, C. K., Wieringa, J. J., \& Wojciechowski, M.F. 2005. Acacia: the case against moving the type to Australia. Taxon 54: 513-519.

Maslin, B. R. 1995. Systematic and phytogeography of Australian species of Acacia: an overview. IFA Newsletter 36: 2-5.

Maslin, B. R., Orchard, A. E., \& West, J. G. 2003a. Nomenclatural and classification history of Acacia (Leguminosae: Mimosoideae), and the implications of generic subdivision. Worldwide Wattle web publication.

Maslin, B. R., Miller, J. T., \& Seigler, D. S. 2003b. Overview of the generic status of Acacia (Leguminosae: Mimosoideae). Australian Systematic Botany 16: 1-18.

Maslin, B. R. 2015. Synoptic overview of Acacia sl (Leguminosae: Mimosoideae) in East and Southeast Asia. Gardens' Bulletin Singapore 67(1): 231-250.

Maslin, B. R. \& Stirton, C. H. 1997. Generic and infrageneric classification in Acacia (Leguminosae: Mimosoideae): a list of critical species on which to build a comparative data set. Bulletin of the International Group for the Study of Mimosoideae 20: 22-44.

McLeish, M. J., Chapman, T. W., \& Schwarz, M. P. 2007. Hostdriven diversification of gall-inducing Acacia thrips and the aridification of Australia. BioMed Central Biology 5: 3 .

Miller, J. T., \& Bayer, R. J. 2000. Molecular phylogenetics of Acacia (Fabaceae: Mimosoideae) based on the chloroplast $\operatorname{trnK} /$ matK and nuclear histone H3-D DNA sequences. In: Advances in legume systematics. Part 9, pp. 181-200. Royal Botanic Gardens, Kew.

Miller, J. T., Andrew, R., \& Bayer, R. T. 2003a. Molecular phylogenetics of the Australian acacias of subg. Phyllodineae (Fabaceae: Mimosoideae) based on the trnK intron. Australian Journal of Botany 51: 167-177.

Miller, J. T., Grimes, J. W., Murphy, D. J., Bayer, R. J., \& Ladiges, P. Y. 2003b. A phylogenetic analysis of the Acacieae and Ingeae (Mimosoideae: Fabaceae) based on trnK, matK, psbA-trnH, and $\operatorname{trnL} / \operatorname{trnF}$ sequence data. Australian Systematic Botany 28: 558-566.

Miller, J. T. \& Bayer, R. J. 2001. Molecular phylogenetics of Acacia (Fabaceae: Mimosoideae) based on the chloroplast matK coding sequence and flanking $\operatorname{trnK}$ intron spacer regions. American Journal of Botany 88: 697-705.

Miller, J. T. \& Seigler, D. S. 2012. Evolutionary and taxonomic relationships of Acacia s.l. (Leguminosae: Mimosoideae). Australian Systematic Botany 25: 217-224.

Murphy, D. J., Brown, G. K., Miller, J. T., \& Ladiges, P. Y. 2010. Molecular phylogeny of Acacia Mill. (Mimosoideae: 
Leguminosae): evidence for major clades and informal classification. Taxon 59: 7-19.

Nylander, J. A. A. 2004. MrModeltest v2. Program distributed by the author. Evolutionary Biology Centre, Uppsala University.

Olmstead, R. G., Michaels, H. J., Scotts, K. M., \& Palmer, J. D. 1992. Monophyly of the Asteridae and identification of their major lineages inferred from DNA sequences of rbcL. Annals of the Missouri Botanical Garden 79: 249-265.

Robinson, J. \& Harris, S. A. 2000. A plastid DNA phylogeny of the genus Acacia Miller (Acacieae, Leguminosae). Botanical Journal of the Linnaean Society 132: 195-222.

Pedley, L. 1986. Derivation and dispersal of Acacia (Leguminosae), with particular reference to Australia, and the recognition of Senegalia and Racosperma. Botanical Journal of the Linnaean Society 92: 219-254.

Pohlman, C. L., Nicotra, A. B., \& Murray, B. R. 2005. Geographic range size, seedling ecophysiology and phenotypic plasticity in Australian Acacia species. Journal of Biogeography 32: 341 351.

Polhill, R. M. 1994. Classification of the Leguminosae and complete synopsis of legume genera. In: Phytochemical dictionary of the Leguminosae. pp 17-38. Chapman and Hall. New York.

Ronquist, F., Teslenko, M., van der Mark, P., Ayres, D. L., Darling, A., Höhna, S., Larget, B., Liu, L., Suchard, M. A., \& Huelsenbeck, J. P. 2012. MrBayes 3.2: Efficient Bayesian phylogenetic inference and model choice across a large model space. Systematic Biology 61(3): 539-542.

Seigler, D. S., Ebinger, J. E., \& Miller, J. T. 2006. The genus Senegalia (Fabaceae: Mimosoideae) from the New World. Phytologia 88: 34-94.

Shinwari, Z. K., Jamil, K., \& Zahra, N. B. 2014. Molecular Systematics of Selected Genera of Family Fabaceae. Pakistan Journal of Botany 46(2): 591-98.

Sulaiman, S. F., Culham, A., \& Harborne, J. N. 2003. Molecular Phylogeny of Fabaceae based on rbcL sequence data: with special emphasis on the tribe Mimoseae (Mimosoideae). Asia Pacific Journal of Molecular Biology and Biotechnology 11: 935.

Sun, Y., Skinner, D. Z., Liang, G. H., \& Hulbert, S. H. 1994. Phylogenetic analysis of Sorghum and related taxa using internal transcribed spacers of nuclear ribosomal DNA. Theoretical and Applied Genetics 89: 26-32.

Swofford, D. L. 2002. PAUP*: Phylogenetic Analysis Using Parsimony (*and Other Methods), version 4.0b10 [computer program]. Sunderland (Massachusetts): Sinauer.

Taberlet, P., Gielly, L., Pautou, G., \& Bouvet, J. 1991. Universal primers for amplification of three non-coding regions of chloroplast DNA. Plant Molecular Biology 17: 1105-1109.

Vassal, J. 1981. 'Acacieae'. In: Advances in Legume Systematics. Part 1, pp. 169-171. Royal Botanic Gardens, Kew.

Warwick, N. W. M. \& Thukten, T. 2006. Water relations of phyllodinous and non-phyllodinous Acacias, with particular reference to osmotic adjustment. Physiologia Plantarum 127: 393-403.

Wojciechowski, M. F., Lavin, M., \& Sanderson, M. J. 2004. A phylogeny of legumes (Leguminosae) based on analysis of the plastid mat $\mathrm{K}$ gene resolves many well- supported subclades within the family. American Journal of Botany 91: 1846-1862. 